Studia nad Autorytaryzmem i Totalitaryzmem 38, nr 3

Wrocław 2016

DOI: $10.19195 / 2300-7249.38 .3 .1$

\author{
OLHA ZOŁOTAR
}

НИИ информатики и права Национальной академии правовых наук Украины

\title{
Права человека - от эпохи Просвещения до информационного общества
}

Интенсивное развитие и влияние высоких технологий на все сферы человеческой жизни привело к созданию нового статуса физического лица - субъекта отношений, который предполагает обладать последними соответствующими правами и обязанностями. Глобальное информационное пространство размывает границы, изменяет способ восприятия действительности, оказывает огромное влияние на формирование человеческой личности, создавая новые угрозы целостности. Человек в современном мире имеет доступ к огромному количеству информации о возможностях и ценностях при условии, что он способен эффективно использовать полученную информацию.

Новые реалии информатизации и глобализации, стремительные социальные изменения объективно ставят общество, государство и каждого человека перед необходимостью переосмысления категорий прав и свобод человека и гражданина. Этим обусловлена актуальность темы данной статьи, являющаяся продолжением научного задела автора, который более 10 лет занимается исследованиями правовых основ информационной безопасности человека в Украине.

Вопросам прав и свобод человека посвящено огромное количество работ различных отраслей науки (и не только) на различных языках мира. Для исследовательских целей автор использовал как научно-методологическую базу англо-, польско-, русско- и украиноязычную научную литературу, статистические данные и результаты других социологических исследований, законодательство и судебную практику, а также публицистику и контент новых медиа. 
Прежде чем перейти к рассмотрению особенностей прав человека в информационном обществе, стоит обратить внимание на становление теории прав человека и теории информационного общества.

Создателями современной доктрины прав человека считаются деятели Просвещения, которые развили на основе античной теории естественных прав и теории общественного договора как источника государственной власти. Монтескье сформулировал принцип разделения властей на законодательную, исполнительную и судебную, и в его работе $O$ Духе законов $(1748)^{1}$ он подчеркнул взаимозависимость между свободой и верховенством закона. Жан-Жак Руссо в работе Об общественном договоре $(1762)^{2}$ определяет общественный договор как основу свободы и равенства, при этом равенство рассматривается им как условие свободы. Целью договора является создание позитивного права и гарантирования свободы и других прав. Неотъемлемый суверенитет народа призван обеспечить защиту прав личности от злоупотреблений власти. Идея свободы занимает центральную позицию в моральной философии Иммануила Канта, должна быть отражена в правовой свободе, на которую имело право каждое человеческое существо в силу его человечности ${ }^{3}$.

Идеи просветителей проложили путь для радикальных изменений в реальности общественной жизни. Еще в конце семнадцатого века были закреплены отдельные гражданские свободы в Англии. Были очерчены права подданных короны, в том числе отдельные процессуальные гарантии и свободы лиц (Habeas Corpus Act 1679 и Билль о правах 1689). Дальше - больше. Во второй половине восемнадцатого века дошло до великих социальных революций: американской и французской, после чего были провозглашены такие эпохальные документы, как Декларация независимости (1776, США) и Декларации прав человека и гражданина (1789 и 1793, Франция). Предыстория и содержание этих деклараций отражает две западные традиции прав. В странах без абсолютных монархий в новой истории люди обладают правами, которые ограничивают правительство. Конституция является высшим законом, писанная либо неписанная, а не воля государя либо государства. В странах с постабсолютизмом государство имеет полномочия, а общество - обязанности. Закон рассматривается как своего рода подарок от государства ${ }^{4}$. До сегодняшнего дня можем видеть это в культуре английского языка, который используется при правотворчестве. В американской традиции, там, как правило, используется понятие народа (people) и правительство (government), что свидетельствует о том, что люди имеют тот же статус, что и госслужащие. Независимые суды защищают права гражданина, стараясь,

1 Ш.Л. Монтескье, О духе законов, Москва 1999, с. 672.

2 Ж.Ж. Руссо, Об общественном договоре, Москва 1998, с. 416.

3 R. Kuźniar, Prawa człowieka, Warszawa 2008, c. 22.

${ }^{4}$ W. Osiatyński, Prawa człowieka i ich granice, Kraków 2011, c. 28.

Studia nad Autorytaryzmem i Totalitaryzmem 38, nr 3, 2016

(C) for this edition by CNS 
чтобы правительство действовало в рамках конституционных полномочий. Правительство находится в подчинении общества, и если оно нарушает права граждан, то должно нести за это ответственность. В законодательстве континентальной Европы наряду с термином народ, как правило, следует государство (state) в различных формах — республика (republic) или монархии (monarchy), что отражает устойчивый характер государства как самого бытия (один из буквальных переводов «state» - статус, положение, определять, устанавливать.) Государство как будто бы «резервирует» за собой монополию на управление обществом - людьми.

Первая концепция, обоснованная в идеях Джона Локка, подчеркивает неотъемлемые права личности и таких «естественных» социальных групп, как семья или церковь; органы государственной власти просто обязаны их уважать. Эта традиция возобладала в семьнадцатом веке в Англии, особенно в американских колониях, которые в восемьнадцатом веке сражались с британским государством. Хотя Англия постепенно отошла от нее, все еще говорится о англо-американской традиции. Стоит отметить, что в Соединенных Штатах идея прав человека не помешала уничтожению местного населения (индейцев) и рабовладению. Джон Локк во Втором трактате о правлении оправдывает систему рабовладения.

В то время на континенте преобладает другая концепция. Государство считается «гарантом общего блага и обеспечителем индивидуальных потребностей» ${ }^{5}$. Как у русского писателя и публициста Николая Некрасова в Забытой деревне: «Вот приедет барин — барин нас рассудит, Барин сам увидит, что плоха избушка, И велит дать лесу», - думает старушка» 6 . Общество государств со стойкими патриархальными традициями власти ожидает «отеческой» заботы от Отечества, что предполагает более широкое понимание общественных обязанностей и обязанностей правительства. На государство возлагается не только обеспечение безопасности и защиты жизни, свободы и собственности, но также обеспечение, при необходимости удовлетворения основных потребностей человека 7 .

Несмотря на многочисленные отличия прототипами актов о правах человека в целом считаются английский Билль о правах (1689), американская Декларация Независимости (1776), и французская Декларация прав человека и гражданина (1789). Но это еще не были «права человека» в современном понимании, только полномочия, которые предоставлялись отдельным людям в рамках определенных обществом.

5 A. Rapaczynski, Popular Sovereighnity and the Conccept of Representation. The Relevance of American Costitutionalism in Eastern Europe, „International Journal of Sociology” 1990, № 4, c. $7-16$.

${ }^{6}$ Н.А. Некрасов, Полное собрание сочинений и писем в 15-ти томах. т. 1. Наука, Лениниград 1981.

${ }^{7}$ L. Henkin, Human rights, New York 1999, c. 302-306. 
Девятнадцатый век отмечен апогеем колониализма и ростом капитализма - с одной стороны, и отменой смертной казни, антиимпериализмом, paбочим движением и началом движения за права женщин - с другой.

В середине девятнадцатого века было инициировано международное гуманитарное движение, в основном в результате преступлений, совершенных в Конго. В 1863 году был сформирован Международный комитет Красного Креста и ратифицирован ряд международных конвенций, ограничивающих произвольное применение силы во время вооруженного конфликта.

Также большее значение приобретают права меньшинств, особенно после первой мировой войны. В ряде договоров и двусторонних соглашений в Европе гарантируется защита жизни и свободы для всех жителей таких стран, как Австрия, Болгария, Венгрия и т.д., а также равные политические и гражданские права для членов всех меньшинств. Хотя эти инструменты оказались неэффективными, положения о защите меньшинств стали отправной точкой для идеи кодификации прав человека в международном праве.

В 1929 году в Нью-Йорке Международный институт права принял Декларацию о международных правах человека, автором которого был русский юрист и жертва большевиков Андрей Мандельштам. Это заявление быстро и широко распространилось в среде неправительственных организаций и университетов.

Необходимость международных гарантий прав человека стала особенно очевидна на фоне событий в Германии. Начиная с 1933 года, когда зарождается «новый немецкий порядок» - вплоть до геноцида, совершенного в Европе. Все это привело к возрождению идеи прав человека в новом свете.

Международные акты - от Атлантической хартии (1941) и Декларации Организации Объединенных Наций (1942) до Уставу Организации Объединенных Наций (1945) - подтверждали важность основных идей прав человека. Все эти идеи «с западными корнями» теперь должны были стать правами человека для всех людей в мире.

Эта идея была привлекательна для западных интеллектуалов и неправительственных организаций, но меньше энтузиазма вызвала у западных правительств, особенно великих держав. Все они были повинны в совершении деяний, противоречащих провозглашенным стандартам: России - большого террора и ГУЛАГа, Англия и Франция — колониализме, США - расизме и официальной расовой сегрегации ${ }^{8}$.

Глендон пишет:

Проект права человека периферической уступкой в пользу малых стран и реакцией на требования многих религиозных и гуманитарных организаций [...] в апреле 1945 года,

8 W. Osiatyński, op. cit., c. 43.

Studia nad Autorytaryzmem i Totalitaryzmem 38, nr 3, 2016

(C) for this edition by CNS 
когда в Сан-Франциско на конференции ООН, было ясно, что доминирующие государства не будут поддерживать идеи прав человека ${ }^{9}$.

Тем не менее, среди официальных представителей более чем 50 стран со всего мира горячими приверженцами Декларации стали делегаты из стран Латинской Америки, к которым впоследствии присоединились представители исламских, буддийских и некоторых африканских независимых государств. На самом деле эта коалиция из малых и бедных стран потребовала принятия Декларации прав человека и имела значительное влияние на ее форму. Принятие Всеобщей декларации прав человека 10 декабря 1948 года считается первым значительным достижением Организации Объединенных Наций в области защиты прав человека. Это было сделано без единого голоса против, с восьмью воздержавшимися. Есть несколько версий, по которым Советский Союз и страны-сателлиты воздержались: то ли из-за отсутствия упоминания о борьбе против фашизма, то ли недостаточного внимания к социально-экономическим правам, или из-за того, что Декларация основана на принципе суверенитета государств, и поэтому противоречит Уставу Организации Объединенных Наций ${ }^{10}$.

Саудовская Аравия воздержалась, потому что протестовала против равенства между женщинами и мужчинами, а также свободы менять религию, гарантированной декларацией. В Южно-Африканской Республике в 1948 году началось построение системы апартеида, что и стало причиной воздержаться при голосовании.

Тем не менее, поддержка стран третьего мира для декларации не значила автоматического внедрения в них прав и свобод личности. С девятнадцатого века философы и политики колониальных стран рассматривали свободу с точки зрения нации, а не отдельных лиц. Идея индивидуальных прав и свобод подчинена идеи самоопределения и построения сильного государства как гаранта прогресса.

Принимая во внимание анализ исторических фактов и научных публикаций, напрашивается парадоксальный вывод — как демократические, так и авторитарные режимы выступают против введения инструментов для обеспечения соблюдения прав человека.

Интересной деталью является полное отсутствие прав меньшинств в Уставе $\mathrm{OOH}$ и Всеобщей декларации прав человека. Такое решение предполагало отказ от идеи предоставления каких-либо коллективных прав немцам после Второй мировой войны. В то же время это устраивало великие государства.

${ }^{9}$ M. Glendon, A World Made New. Eleanor Roosevelt and the Universal Declaration of Human Rights, New York 2001, c. 15.

10 J. Kolarzowski, Powszechna Deklaracja Praw Człowieka - historycznym przełomem, Biuletyn Olimpiady Filozoficznej, № 7, Warszawa 1994, http://www.racjonalista.pl/kk.php/s,4710 (дата обращения: 24.03.2015). 
Всеобщая декларация прав человека стала результатом многих компромиссов, сочетая различные традиции и ценности. Во-первых, она объединила обе вышеупомянутые западные традиции понимания прав. Основная часть декларации в соответствии англо-американской традиции касается базовых прав и свобод проблем «каждого», а также политических и гражданских прав, но ключевое понятие достоинства происходит из христианской мысли. Идея свободного и полного развития личности взята из персоналистической философии Жака Маритена ${ }^{11}$.

Важными элементами этого синтеза является соединение свободы с экономической безопасностью, и с главной целью Декларации - сохранением мира во всем мире. По этой причине, гражданские свободы и политические права, как и права социально-экономические и культурные, рассматривались важными в равной степени. Расширен также по сравнению с каталогом прав восемнадцатого века круг носителей этих прав. Вместо понятия «лицо» употребляется понятие «человек», чьи права не проистекают из договора, но непосредственно связанны с достоинством.

Декларировалось, что права человека являются всеобщими. Тем не менее, Всеобщая декларация прав человека (как и любая друга) имеет место быть в пространстве и времени. Это порождает множество вопросов: если права существовали испокон веков, укоренены в природе человека, почему же их обнаружила только часть человечества? Как объяснить тот факт, что общества, провозгласившие универсальность прав, не признают права других обществ на собственное видение? Концепция универсальности также является проблемой. О какой универсальности идет речь - географической, философской или моральной? Раймундо Паниккара ставит под сомнение всеобщность прав: «Имеет ли смысл вопрос о выполнении условий универсальности, если тот же вопрос универсальности далеко не всеобщая проблема?» ${ }^{12}$.

На этапе создания второго поколения прав человека принцип универсальности применялся с целью устранения различий. Ален де Бенуа, французский писатель, политолог и журналист, отмечает: «теория прав человека, кажется, мало склонна признавать культурное разнообразие по двум причинам: во-первых, из-за фундаментального индивидуализма и крайне абстрактной природы объекта, которому предоставляются права; во-вторых, из-за её тесных связей с Западной культурой».

Если мы предположим, что идеология прав человека вопреки её западным корням, по-настоящему универсальна, возникают трудности на уровне

11 Ж. Маритен, От Бергсона к Фоме Аквинскому. Очерки метафизики и этики, „Bibliotheca Ignatiana”, Институт философии, теологии и истории св. Фомы, 2006, с. 216.

${ }^{12}$ La notion des droits de l'homme est-elle un concept occidental?, „Diogène”, październikgrudzień 1982, с. 88. Текст повторно был опубликован в „La Revue du MAUSS” 1999, c. 211235, пер. J. Dębowska, O. Swolkień. 
терминологии. Термин «право» в смысле индивидуального свойства лица в средневековье не существовал в любом европейском языке. Это означает, что длительное время не существовало даже слова для обозначения прав лиц, которые бы принадлежали им в силу их человечества. Этот факт, как оценивает Макинтайр, ставит под сомнение реальность и смысловое наполенение этих прав ${ }^{13}$.

В арабском, иврите, китайском, японском языках и хинди термины, используемые для обозначения прав человека, не предусматривают их универсальности. (yukt и ucita (правильный), nуауаta (справедливый), dharma (обязанность), китайский — chuan и li — власть и интересы, арабский haqq - закон, который прежде всего означает истину) ${ }^{14}$.

Вторым вызовом становится универсальность теории человеческой природы независимо от времени и места. Её интерпретация приводит к тройному противопоставлению: между человеком и другими живыми существами (человек является единственным носителем естественных прав?), между человеком и обществом (человеческая личность, по сути, индивидуалистична; социальная среда не определяет ее характера?), а также между человеком и всей Вселенной (человеческая природа не связана с всеобщим порядком вещей? $)^{15}$. Аналогичное противопоставление не встретишь в большинстве незападных культур. Очередную сложность создает концепция индивидуализма. У источников европейской культуры лицо (или личность) само по себе не имеет места быть. Оно рассматривается как часть семьи, рода либо народа, составляющая бытия Вселенной.

В холистических культурах концепция индивидуальных прав не существует, поскольку они отрицают восприятие человека как самодостаточного атома, и доминируют категории двусторонних обязательств.

Несмотря на все несоответствия, концепция двадцатого века проложила путь к правам «третьего поколения», которым требовалась новая роль государства. Она признает суверенитет государства над гражданами, и в то же время дополняет его стандартами международного права и международной системой обеспечения. Забегая вперед, Конвенция о защите прав человека и основных свобод и Хартия основных прав ЕС расширит права человека в географическом смысле - за пределы национальных государств. После исчерпания имеющихся национальных способов защиты, любой гражданин может индивидуально обратиться в Европейский суд по правам человека. В то же время, в системе ООН против государства выступить может не гражданин, права которого были нарушены, но другое государство.

13 A. Benoist, Etnobójcza ideologia Zachodu. Prawa człowieka i prawa narodów, „Eléments” 2003, № 109, цит. за „Obywatel” 2005, № 3 (23), http://nowyobywatel.pl/kwartalnik/numeryarchiwalne/ (дата обращения: 1.04.2015).

${ }^{14}$ Ibidem.

Studia nad Autorytaryzmem i Totalitaryzmem 38, nr 3, 2016

(C) for this edition by CNS 
Многочисленные исторические события свидетельствуют о нередком использовании двойных стандартов. Например - один из создателей ВДПЧ Рене Кассин, который выступал за культурный релятивизм в колониальных войнах, писал: «в отсталых колониальных обществах права человека могут поставить под угрозу общественный порядок» ${ }^{16}$.

Во время холодной войны политики неохотно обращались к правам человека. У каждого государства были на то собственные причины. СССР был погружен в сталинском терроре, Китай строил коммунизм, Соединенные Штаты больше заботились о собственном суверенитете. Что интересно, Соединенные Штаты не поддерживали идею индивидуальных прав человека на международном уровне. Джон Фостер Даллес заявил, что США «не будет участником какого-либо документа по правам человека, принятого Организацией Объединенных Наций» ${ }^{17}$.

И только в 1966 году стало возможным принятие следующие актов по правам человека - Международного пакта о гражданских и политических правах и Международного пакта об экономических, социальных и культурных правах ${ }^{18}$. С этого момента можем говорить о политизации прав человека. Более того, после Конференции по безопасности и сотрудничеству в Европе, права человека не только в Европе получили широкое признание и поддержку правозащитников в странах Восточного блока. В заключительном акте конференции было установлено право «знать о своих правах», которое можно считать прекурсором информационных прав человека.

Ошибкой будет считать, что существовали только западные модификации прав. Не вдаваясь в подробности, теоретики коммунистического лагеря предлагали их «социалистическую концепцию прав человека. Отвергая естественное право и справедливость в качестве источника, она основывалась на нормах позитивного права. Социалисты провозглашали взаимную связь прав и обязательств. Каждому праву гражданина должна соответствовать обязанность государства.

Взаимосвязь прав и обязанностей находим также в социальном учении Католической церкви. Однако, согласно этому учению, ее источником является естественное право ${ }^{19}$.

В конце XX века в большинстве конституций мира были закреплены права человека. Венская декларация 1993 года заявляет о поощрении и защите прав человека как вопросе первостепенного значения для международного

16 R. Burke, The Complling dialogue of Freedom. Human rights at the Bandung Conference, „Human Rights Quarterly” 28, 2006, c. 962.

17 M. Ignatieff, Human rights. The Midlife Crisis, „The New York Review of Books” 1999, 20, c. 59 .

18 США не ратифицировал последний.

19 Больше: Pacem in Terris, http://www.opoka.org.pl/biblioteka/W/WP/jan_xxiii/encykliki/ pacem_in_terris_11041963.html (дата обращения: 2.04.2015). 
сообщества и одновременно расширяет перечень прав для таких категорий как беженцы, перемещенные лица, меньшинства, женщины и дети, инвалиды и т.д. В 90-тых годах международное сообщество приняло ряд конвенций по защите прав меньшинств - Декларация о правах лиц, принадлежащих к национальным или этническим, религиозным и языковым меньшинствам (1992), Рамочная конвенция о защите национальных меньшинств (1995). Права человека стали источником стандартов для международных трибуналов, в том числе Международного уголовного суда.

По завершению холодной войны, падению коммунизма, преодолению апартеида и распространения идей демократизации, могло показаться, что идея прав человека принята повсеместно. Но, как оказалось, чтобы «победить» идеологические угрозы в современном мире, под угрозой оказалась сама идея прав человека.

В материалах Европейской региональной конференции, организованной Комиссией Франции по делам ЮНЕСКО и Советом Европы «Этика и права человека в информационном обществе» есть мнение, с которым не может не согласится автор:

В 1950 г. было проще провозглашать всеобщие права человека (в частности, свободу выражения мнений), чем сегодня, когда в своем собственном доме и в своей частной жизни мы сталкиваемся со столь разнообразными представлениями о мире ${ }^{20}$.

На рубеже XX и XXI веков информационная революция затронула все сферы жизнедеятельности общества — политику, экономику, право, государственное управление и международные отношения, финансы, науку, образование, культуру. Информационные ресурсы общества стали определяющим фактором его развития и большинство стран констатировали начало новой эпохи - информационного общества. Впервые достаточно четко представления об информационном обществе были сформулированы в 60-х-начале 70-х годов двадцатого века. Не вдаваясь в подробности развития, отметим, что в течение нескольких десятилетий термин «информационное общество» переместился из сферы футорологии в лексикон специалистов по информационно-коммуникационным технологиям, и в начале тысячелетия - стал широко употребляем политическими деятелями, экономистами, учеными и т.д. В 1998 году на Полномочной конференции Международного телекоммуникационного союза принята резолюция о проведении Всемирного саммита по вопросам информационного общества (WSIS). В 2000 году на саммите стран Большой восьмерки была принята Окинавская хартия глобального информационного общества. В 2002 году Генеральная ассамблея $\mathrm{OOH} \mathrm{приняла} \mathrm{резолюцию} \mathrm{о} \mathrm{проведении} \mathrm{двухэтапного} \mathrm{Всемирного} \mathrm{саммита}$

${ }^{20}$ Ethics and human rights in the information society. Proceedings, synthesis and recommendations. Organized by the French Commission for UNESCO in cooperation with UNESCO and the Council of Europe, 13-14 September 2007, Strasbourg, c. 18. 
по вопросам информационного общества, а в 2003 и 2005 годах происходят Женевский и Тунисский этапы этого саммита. Международное сообщество пришло к единому мнению, что права, закрепленные во Всеобщей декларации прав человека, должны быть реализованы в информационную эпоху, находиться под защитой государства и общества вне зависимости от развития и внедрения новых технологических достижений ${ }^{21}$.

В Окинавской хартии было закреплено, что

все люди повсеместно, без исключения должны иметь возможность пользоваться преимуществами глобального информационного общества. Устойчивость глобального информационного общества основывается на стимулирующих развитие человека демократических ценностях, таких как, свободный обмен информацией и знаниями, взаимная терпимость и уважение к особенностям других людей ${ }^{22}$.

В то же время в информационном обществе преобладает децентрализованность, разрушается традиционная иерархическая система ценностей.

Кардинально меняется и трактовка понятий «человек» и «его личность». Организующим принципом культурной жизни человека становится принцип трансформации. Свобода личности становится гарантом ее безопасности ${ }^{23}$.

Джон Локк утверждал, что существуют две силы, посредством которых «человек защищает свои естественные права [...] первая — делать то, что он считает необходимым дабы сохранить себя и других на основе законов природы, вторая - наказывать за преступления, совершенные в нарушение закона» ${ }^{24}$. Право на безопасную окружающую среду относится к естественным правам. Тем не менее, под этой средой, в классическом понимании, имели ввиду окружающую среду. Как же быть с информационной средой?

Человек приспосабливается к социальной жизни, воспринимает социальные роли, принимая и передавая определенную информацию. Каждый становится членом общества через усвоение и соблюдение (или отрицание и нарушение) социальных норм, которые исторически сложились в нем. Именно поэтому общество становится носителем одной из самых серьезных угроз для информационной безопасности человека — информационный дискриминации, которая проявляется не только в разделении людей на тех, кто имеет доступ к информации, и тех, кто его не имеют. На ряду с понятием

21 UN General Assembly Resolution (Резолюция Генеральной Ассамблеи ООН) 217 A (III) от 10 декабря 1948 г., Материалы ЮНЕСКО об информационном обществе. ЮНЕСКО, 2003.

22 Окинавская хартия глобального информационного общества: рекомендации стран «восьмерки» о принципах и направлениях развития информационного общества, Окинава, 22 июля 2000 г., «Дипломатический вестник” 2000, № 8, с. 51-56.

23 А.А. Мищериков, Безопасность и свобода личности в информационном обществе: анализ проблемы, ,Теория и практика общественного развития” 2011, № 1, http://cyberleninka. $\mathrm{ru} /$ article/n/bezopasnost-i-svoboda-lichnosti-v-informatsionnom-obschestve-analiz-problemу (дата обращения: 2.02.2016).

24 С. Головатий, Верховенство права, Киев 2006, с. 215. 
«информационного общества» в международный обиход вошло понятие «digital divide» - цифрового разрыва или цифровой пропасти. Эта концепция появилась в 1995 году после публикации отчета от Министерства торговли США о исследованиях доступа граждан к компьютерам и Интернету (Falling Through the Net 1995), и первоначально подразумевало деление общества на подключенное и не подключенное к глобальной сети Интернет ${ }^{25}$.

Сначала проблема цифрового разрыва была расценена как чисто американская и обсуждалась только в США. Однако, позже стало очевидным ее глобальность. На саммите стран Большой восьмерки (G8) в Окинаве и позже в Женеве шла речь о «мобилизации ресурсов для улучшения информационной и коммуникационной инфраструктур, поскольку они являются одним из наиболее важных факторов влияющих на общество XXI века. Разрыв между теми, кто имеет доступ к компьютерным технологиям и теми, кто лишен такой возможности, проявляется в самых разных сферах жизни общества, в том числе ограничивает возможности в поиске работы, налаживании социальных связей, культурном обмене и может негативно влиять на экономическую эффективность, развитие и сохранение культуры, уровень образования. Условия для соблюдения прав человека в информационном обществе зависят не только от степени благоприятствования информационной среды, но также от внутренних характеристик самого субъекта (например, информационного потенциала, когнитивности, способности к саморазвитию).

Согласно концепции информационного общества, его спецификой является возможность свободного обмена информацией, которая способствует преодолению нищеты и неравенства. Однако есть и обратная сторона медали, как утверждает один из основоположников концепции «сетевого общества» Мануэль Кастельс:

Глобальный тренд заключается в том, что информационная экономика подключает к своей сети тех, кто представляет для неё ценность (тем самым придавая им дополнительную ценность), но отключает тех, кто не имеет для неё ценности (тем самым ещё более уменьшая их шансы обрести какую-то ценность) $)^{26}$.

Одним из основных этических и правовых принципов, который в связи с этим претерпевает переосмысление, является «уважение достоинства человека и его изначальной автономности (способности управлять самим собой, основываясь на собственных принципах $)^{27}$, то есть способности к личному развитию. Достоинство, согласно учению Канта, означает убеждение в том,

25 National Telecommunications and Information Administration. 1995. Falling Through the Net: A Survey of the "Have-Nots" in Rural and Urban America. Washington DC: NTIA, http:// www.ntia.doc.gov/ntiahome/fallingthru.html (дата обращения: 12.05.2015).

26 П. Химанен, М. Кастельс, Информационное общество и государство благосостояния. Финская модель = The Information Society and Welfare State: The Finnish Model, Логос 2002, c. 224.

27 И. Кант, Сочинения в 6 m., т. 2, Москва 1964, с. 206. 
что человек есть самоцель и что он никогда не может быть средством для достижения цели, будь то экономика или безопасность. Именно этот этический принцип лежит в основе Устава ЮНЕСКО, что и отражено в его преамбуле (довольно любопытно, что с 1998 г. этот же принцип провозглашен одной из фундаментальных ценностей Конфедерации европейских ассоциаций пользователей компьютеров). Можно ли говорить о достоинстве теперь, в эпоху «Интернета вещей», где ценность человека, точнее, его статус в сетях, работу которых он не может контролировать, оказывается низведенным до статуса окружающих его вещей, с которыми он взаимодействует? Можно ли говорить об уважении личности, когда системы функционируют в непрозрачном режиме на основе баз данных или метаданных, удаленных от индивидуального «я»? ${ }^{28}$

Человек в информационном обществе сталкивается с опасностями и угрозами абсолютно нового порядка и качества. Казалось бы, классические права и свободы приобретают новое понимание. Информационная среда не совпадает с привычной для общества временно-пространственной; нормы, разработанные для регулирования отношений в (реальном) обществе, не всегда адаптируемы для этой зачастую виртуальной реальности.

Сегодня грань между реальным миром и виртуальным очень нечетка. «Наши телефоны и фотоаппараты становятся глазами и ушами» — говорит Тим О'Рейли, издатель книг на компьютерную тематику. Глобальная сеть постепенно заменяет весь мир - и все потому, что все в мире отбрасывает так называемые «информационные тени» ${ }^{29}$. Распространение массовой культуры, неизбежно столкновение виртуальной реальности, в которой трудно провести различие между иллюзией и реальностью, создает не только психологические и культурные проблемы, но также правовые. Создавая свой образ в виртуальном пространстве, человек теряет адекватное восприятие реального мира, в том числе правового аспекта. Сегодня, более чем у девяти миллионов землян, есть «вторая жизнь» в Интернете, подавляющее большинство из них - дети и молодые люди ${ }^{30}$. Филипп Росдэйл, основатель «Second Life», как-то сказал: «Я не создаю новую игру, а новое государство» ${ }^{31}$. И в самом деле, виртуальная реальность (не важно, то ли это виртуальные миры, то ли социальные сети) существенно влияет на жизнь человека в реальном обществе.

Причины этого многочисленны, начиная от психологических механизмов ответственности, уверенности в себе и самозащиты. С психологической

28 Ethics and human rights in the information society. Proceedings..., c. 11.

29 О. Беркмен, Зникла межа між віртуальним і матеріальним світами, http://osvita. telekritika.ua/print/material/2099 (дата обращения: 21 февраля 2011).

30 О. Золотар, Віртуальна реальність, „Моделі колективної безпеки: інформаційний вимір", Україна, Київ 2011, с. 63-66.

31 Віртуальний світ — це вже реальність. Секонд лайф, «Новини» ТСН, 17.06.07 г., http://pokrovka.2bb.ru/viewtopic.php?id=157 (дата обращения: 10.07.2010). 
точки зрения, Интернет рассматривается человеком как нечто вроде толпы. И в толпе, насколько известно, исчезают чувства собственной идентичности, вместе с ней - чувство ответственности. Толпа анонимна, а значит безответственна ${ }^{32}$.

В толпе значительно снижается уровень интеллекта по отношению к уровню интеллекта отдельных лиц; повышается восприимчивость на внушение и манипулирование сознанием, понижается уровень способности мыслить рационально. Вы можете унизить человека. Можно устроить скандал, к которому присоединятся все те, кто в это время оказался на злосчастной странице и т.п. Ощущение, что можно избежав ответственности, повысить самооценку «за чужой счет», и в то же время, чтобы уйти от реальности, обзывая кого-то в чате «гнилой кацап / лях / хохол / жид» превалирует в сознании многих граждан.

Виртуальный мир можно рассматривать как потенциальный источник мошенничества. В нем зарабатываются деньги, но отсутствуют налоги, есть работа - нет норм, защищающих социальные права, есть кражи виртуальных товаров - отсутствуют органы преследования ${ }^{33}$.

Более того, необходимо, Интернет призван содействовать развитию автономности не только на уровне отдельного человека, но и на уровне нации, а в конечном итоге - человечества в целом. То, что Интернет позволяет каждому сообществу высказываться, обогащать и расширять собственную культуру, подразумевает признание за каждым языком права на пространство для существования, а за каждой нацией - права на обладание средствами собственных форм самовыражения ${ }^{34}$.

Одним из существенных различий, которые препятствуют осуществлению качественной коммуникации в сети, есть языковая диспропорция. Она основана на доминировании английского языка как основного языка Интернет, программного обеспечения и технической поддержки компьютерных систем и телекоммуникаций. Расцвет английского языка как инструмента глобализации не только оставляет мало места для других языков в киберпространстве, но и ограничивает доступ к знаниям и общению для тех, кто нуждается в них больше всего.

Доминирование английского языка в области научно-технических знаний приводит к нивелированию ценности (и иногда потере) знаний, выраженных в других языках. Критерий экономической видимости, который управляет глобальным информационным обществом, зачастую исключает «невидимые» знания. Невидимые знания - представляет собой

32 G. Le Bon, Psychologia ttumu, пер. B. Kaprocki, Kęty 2004, c. 95.

33 W. Wrzos, Wszystko, co musisz wiedzieć o handlu wirtualnymi dobrami w grach, http:// www.komputerswiat.pl/artykuly/redakcyjne/2013/11/handel-wirtualnymi-dobrami-w-grach.aspx (дата обращения: 10.05.2015).

34 Ethics and human rights in the information society. Proceedings..., c. 11. 
неоднородную совокупность знаний, почти подразумеваемого характера, невыраженные в текстовой форме и часто передаваемые устно из поколения в поколение, в постоянном взаимодействии с природой; а также - знания местных и коренных народов ${ }^{35}$, поскольку экономика основывается прежде всего на обработке «оцифрованных» знаний, превращенных в данные. Из-за этого весьма ощутимой становится угроза укрытых форм «техно-апартеида».

Таким образом, что мы имеем в конечном итоге. Деятели эпохи Просвещения и их последователи сформировали либо актуализировали ряд научных теорий, которые были жизненно необходимы для обеспечения развития государства и общества, в т.ч. прав человека, суверенитета, разделения власти, теории национального государства и т.п. Но их интерпретация и жизнеспособность находится в постоянной зависимости от общества, в котором они имеют место быть. Информационное общество, как новый этап бытия, порождает необходимость пересмотреть временно-пространственный подход к классической теории прав человека. Смысловое наполнение отдельно взятых прав человека видоизменяется постоянно, практически в каждом виде прав человека появляется его «информационная» составляющая связанная с доступом к информации, защитой уязвимых данных, информационно-психологической безопасностью т.д. Ошибкой будет рассматривать «информационное общество» только в качестве либерализации в телекоммуникациях, и развитие отрасли информационных технологий, не выходя за рамки технологической точки зрения на сущность «информационного общества». Сама теория информационного общества также подвергается значительной научной критике ${ }^{36}$. Не это главное.

Человек остается главной ценностью любого общества, в том числе информационного, поэтому вопрос, как защитить его права и свободы еще более актуален при наличии новых угроз не только для свободы развития личности, но и для ее физической и психологической целостности.

\section{Библиография}

Беркмен О., Зникла межа між віртуальним і матеріальним світами, http:/osvita.telekritika.ua/ print/material/2099, 21 лютого 2011.

Віртуальний світ - ие вже реальність. Секонд лайф, «Новини» ТСН, 17.06 .07 г., http:// pokrovka.2bb.ru/viewtopic.php?id=157.

Золотар О., Віртуальна реальність, «Моделі колективної безпеки: інформаційний вимір», Київ, НДЦП НАПрН України 2011, с. 63-66.

Маритен Ж., От Бергсона к Фоме Аквинскому. Очерки метафизики и этики, «Bibliotheca Ignatiana», Институт философии, теологии и истории св. Фомы, 2006.

35 Towards Knowledge Societies, Paris, UNESCO 2005, c. 150, 237.

${ }^{36}$ L.Z. Karvalics, Z. Laszlo, How to defend the original, multicriteria theories of Information Society?, 3rd ICTs and Society Meeting; Paper Session — Theorizing the Internet; Paper 3. (Publication in «tripleC - Cognition, Communication and Co-operation» 2010, № 2, www.triple-c.at).

Studia nad Autorytaryzmem i Totalitaryzmem 38, nr 3, 2016

(C) for this edition by CNS 
Мищериков А., Безопасность и свобода личности в информационном обществе: анализ проблеMbl, «Теория и практика общественного развития» 2011, № 1, http://cyberleninka. ru/article/n/ bezopasnost-i-svoboda-lichnosti-v-informatsionnom-obschestve-analiz-problemy (дата обращения: 2.02.2016).

Монтескье Ш.Л., О духе законов, Москва 1999.

Некрасов Н.А., Полное собрание сочинений и писем в 15-ти томах, т. 1. Наука, Лениниград 1981.

Окинавская Хартия глобального информационного общества: рекомендации стран «восьмерки» о принципах и направлениях развития информационного общества, Окинава, 22 июля 2000 г., «Дипломатический вестник» 2000, № 8, с. 51-56.

Руссо Ж.Ж., Об общественном договоре, Москва 1998.

Химанен П., Кастельс М., Информационное общество и государство благосостояния. Финская модель = The Information Society and Welfare State: The Finnish Model, Логос 2002.

Benoist A., Etnobójcza ideologia Zachodu. Prawa człowieka i prawa narodów, „Eléments” 2003, № 109, цит. за „Obywatel” 2005, № 3 (23), http://nowyobywatel.pl/kwartalnik/numeryarchiwalne/ (дата обращения: 1.04.2015).

Burke R., The Complling dialogue of Freedom. Human rights at the Bandung Conference, „Human Rights Quarterly" 28, 2006, c. 962.

Ethics and human rights in the information society, https://www.internetsociety.org/ethics-and-human-rights-information-society (дата обращения: 10.07.2010).

General UN Assembly Resolution (Резолюция Генеральной Ассамблеи ООН) 217 А (III) от 10 декабря 1948 г., Материалы ЮНЕСКО об информационном обществе. ЮНЕСКО, 2003.

Glendon M., A World Made New. Eleanor Roosevelt and the Universal Declaration of Hu man Rights, New York 2001.

Henkin L., Human rights, New York 1999.

Ignatieff M., Human rights. The Midlife Crisis, „The New York Review of Books” 1999, 20.

Karvalics L.Z., Laszlo Z., How to defend the original, multicriteria theories of Information Society?, 3rd ICTs and Society Meeting; Paper Session - Theorizing the Internet; Paper 3. (Publication in «tripleC - Cognition, Communication and Cooperation» 2010, № 2 (www.triple-c.at).

Kolarzowski J., Powszechna Deklaracja Praw Człowieka - historycznym przełomem, Biuletyn Olimpiady Filozoficznej 7, Warszawa 1994, http://www.racjonalista.pl/kk.php/s,4710 (дата обращения: 24.03.2015).

Kuźniar R., Prawa czlowieka, Warszawa 2008.

La notaion des droits de l'homme est-elle un concept occidental?, „Diogène”, październik-grudzień 1982, с. 88. Цит. за „La Revue du MAUSS” 1999, с. 211-235, пер. J. Dębowska, O. Swolkień.

Le Bon G., Psychologia thumu, tlum. B. Kaprocki, Kęty 2004.

National Telecomunications and Information Administration. 1995. Falling Through the Net: A Survey of the "Have-Nots" in Rural and Urban America. Washington DC: NTIA, http:// www. ntia.doc.gov/ntiahome/fallingthru.html (дата обращения: 12.05.2015).

Osiatyński W., Prawa człowieka i ich granice, Kraków 2011.

Pacem in Terris, http://www.opoka.org.pl/biblioteka/W/WP/jan_xxiii/encykliki/pacem_in_terris_11041963.html (дата обращения: 2.04.2015).

Rapaczynski A., Popular Sovereighnity and the Conccept of Representation. The Relevance of American Costitutionalism in Eastern Europe, „International Journal of Sociology” 1990, № 4, c. $7-16$.

Towards Knowledge Societies, Paris, UNESCO 2005.

Wrzos W., Wszystko, co musisz wiedzieć o handlu wirtualnymi dobrami w grach, http://www.komputerswiat.pl/ artykuly/redakcyjne/2013/11/handel-wirtualnymi-dobrami-w-grach.aspx (дата обращения: 10.05.2015). 


\section{HUMAN RIGHTS - FROM THE ENLIGHTENMENT \\ TO THE INFORMATION SOCIETY}

\section{Summary}

The author of the article analyses the origins of human rights from the Enlightenment period to the information society. First, she points to the establishment and development of the idea by Enlightenment thinkers. Speaking of the historical development of human rights, we have to bear in mind that it is not about the emergence or evolution of human rights as such. Their development is determined by socio-political conditions and spatial-temporal factors.

Social transformation leading to the emergence of the information society has shaped awareness of human rights in the sense that information and communication technologies should not be regarded as an end in themselves. Next the author examines the problem of informational exclusion or digital divide as well as the impact of the virtual reality on people's lives in real society.

Keywords: human rights, informational society.

Olha Zołotar

zolotarolga@gmail.com 